\title{
Growth performance, carcass traits, and blood biochemistry of broiler chicks fed with low-fibre sunflower meal and phytase
}

\author{
G. Ciurescu ${ }^{1}$, A. Vasilachi ${ }^{1 \#}$, D. Grigore ${ }^{1,3}$ \& H. Grosu ${ }^{1,2}$ \\ ${ }^{1}$ National Research-Development Institute for Biology and Animal Nutrition \\ Calea Bucuresti no. 1, Baloteşti, 077015, Ilfov, Romania \\ ${ }^{2}$ Department of Genetics and Animal Breeding, ${ }^{3}$ Department of Biotechnology, Doctoral School, University of Agronomic \\ Science and Veterinary Medicine, Bucharest, 59 Marasti Street, 011464, Bucharest, Romania
}

(Received 11 March 2019; Accepted 04 June 2019; First published online 13 August 2019)

Copyright resides with the authors in terms of the Creative Commons Attribution 4.0 South African License.
See: http://creativecommons.org/licenses/by/4.0/za
Condition of use: The user may copy, distribute, transmit and adapt the work, but must recognize the authors and the South African
Journal of Animal Science.

\begin{abstract}
This study was designed to evaluate the impact of graded replacements of soybean meal (SBM) with low-fibre sunflower meal (LF-SFM), with and without phytase supplementation, on growth performance, carcass traits, and plasma profile of broilers. A total of 800 mixed sex one-day-old broiler chicks (Cobb 500) were randomly assigned to eight dietary treatment groups (five replicates each) in a $4 \times 2$ factorial arrangement, including four levels of LF-SFM (0\%, 25\%, 50\%, and $75 \%$ to replace SBM) and two levels of microbial phytase ( 0 or $0.2 \mathrm{~g} / \mathrm{kg}$ diet). Feed conversion ratio (FCR), and bodyweight gain (BWG) were decreased significantly if LF-SFM replaced more than $25 \%$ SBM. There was no significant effect between the interaction of the main factors (LF-SFM $\times$ phytase) on growth performance during the starter, grower, finisher and the overall period. The addition of phytase had no beneficial effects on performance traits. Carcass traits were not influenced by feeding LF-SFM or enzyme addition. However, increasing the level of LF-SFM ( $50 \%$ and $75 \%$, respectively) in diets reduced the abdominal fat, whereas the weight of the small intestine was increased. Plasma metabolic profile was not affected by LF-SFM levels in broiler diets, except for high-density lipoproteins cholesterol (HDL-C) and total cholesterol (T-Cho), which were not affected by the dietary enzyme. It is concluded that the diets with LF-SFM levels up to $25 \%$ generated growth performance and carcass traits comparable with the diet that contained SBM.
\end{abstract}

Keywords: Cobb 500, digestive organs, enzyme, growth traits, low-fibre sunflower meal, plasma profile

\#Corresponding author: andryca82@yahoo.com

\section{Introduction}

The utilization of soybean protein in human food and animal feeds may cause problems in the future, such as availability, production costs, and the risks associated with reliance on a single ingredient. Soybean meal (SBM) is the main protein source in poultry feed, and is usually known for its high quality (NRC, 1994). SBM comes mostly from genetically modified crops. This situation encourages European Union (EU) countries to find ways to reduce dependence on imported protein feeds, which would increase the security of feed supply (Ciurescu et al., 2017). Utilizing agro-industry by-products as inexpensive alternatives in poultry nutrition is of ongoing interest for nutritionists and poultry producers.

Sunflower (Helianthus annuus L.) is a high oil-yielding seed crop that is cultivated worldwide, and adapts well to a wide range of climatic and soil conditions. Sunflower meal (SFM) is an important by-product of sunflower oil extraction, which is a source of vegetable protein and fibre for human beings and animals (Kalmendal et al., 2011). Its protein content depends on dehulling, air-classification, and oil extraction processes (Laudadio et al., 2013). Additionally, SFM contains low antinutritional compounds, such as chlorogenic acid (Canibe et al., 1999), and is more resistant to contaminants, compared with SBM (Bozzo et al., 2008). Nevertheless, the use of SFM in poultry diet is limited by variations in its chemical composition. The two main components that restrict its use are its high fibre and low lysine contents (Rezaei \& Hafezian, 2007; de Morais Oliveira et al., 2016). One of these issues may be overcome by reducing the fibre content of SFM. The application of micronization, coupled with air fractionation, was considered a useful tool for improving some technological performances and nutritional properties and enriching the meal fractions of 
healthy compounds (Rizzello et al., 2012). High SFM levels in broiler diets require the addition of high levels of oil to compensate for the low energy content of this ingredient. Nevertheless, according to current market prices, oil seems to be one of the most expensive feedstuffs in broiler diets.

Phosphorus $(P)$ is the third most expensive nutrient in poultry diets after energy and protein (Biehl et al., 1998). Phytic acid (myo-inositol hexaphosphate) is an important plant $P$ storage form and accounts for $50 \%$ to $80 \%$ of total $\mathrm{P}$ in plant seeds that are commonly used in livestock animal feeds. However, phytate-P has low bioavailability and is underutilized owing to the lack of endogenous phytate degrading enzymes in nonruminant livestock, including poultry (Selle et al., 2006).

Phytase (myo-inositol-exakisphos-phohydrolase), a specific phosphohydrolase, degrades phytate to yield inositol monophosphate and orthophosphate via inositol penta- to monophosphates as intermediary products (Liu et al., 1998). In-feed administration of microbial phytases to improve the digestibility of phytic acid is widely used in the production of poultry and other livestock (Simons et al., 1990; Selle et al., 2007; Cowieson et al., 2011). Promising results have been reported when some exogenous enzyme is added to chicken, guinea fowl and quail diets that contain SFM to aid fibre digestion (carbohydrases) or to solubilize phytate-P (phytase), thereby reducing their negative effects on broiler production parameters (Mandal et al., 2005). However, no research appears to have been reported on the application of phytase in broiler diets containing low-fibre SFM (LF-SFM).

Thus, the objective of this study was to evaluate an appropriate inclusion level of LF-SFM in chicks' diet as an alternative protein source instead of SBM, with or without microbial phytase supplementation, on the productive performance, digestive organ size and plasma biochemistry of broilers.

\section{Materials and Methods}

The study protocol was approved by the Local Ethical Committee for Animal Experiments in Balotesti, and was in accordance with the principles of EU Directive 2010/63/EU and Romanian Law on Animal Protection.

One-day-old Cobb 500 broiler chickens $(n=800)$ of mixed sex were purchased from a local commercial hatchery, weighed (43.4 $\pm 0.23 \mathrm{~g} /$ chick) individually, and randomly distributed to one of the eight dietary treatments in a 42-day feeding trial. Each treatment was sub-divided into five replicates, which were reared in pens of equal size $(1.9 \times 1.0 \mathrm{~m})$ and considered one block. Pens were arranged in longitudinal lines in the house. The chicks were vaccinated at hatch for Marek disease, infectious bronchitis, and Newcastle disease and were raised on wood shavings litter. Heat was provided with a heating lamp per pen. Except for day 1, a 23-hour light to 1-hour dark lighting programme was applied during the experiment. The temperature was maintained at $32{ }^{\circ} \mathrm{C}$ at placement, followed by a $3{ }^{\circ} \mathrm{C}$ decrease each week to achieve $20-$ $21^{\circ} \mathrm{C}$ by using thermostatically controlled heaters, fans, and adjustable sidewall inlets. The main diets were arranged in a $4 \times 2$ factorial design, with the variable being LF-SFM, which replaced SBM on four levels $(0 \%$, $25 \%, 50 \%$, and $75 \%$, respectively) and enzyme supplementation at two levels (0 and $0.2 \mathrm{~g} / \mathrm{kg}$ diet, respectively). The microbial phytase (Axtra ${ }^{\circledR}$ PHY 5000 L, a Buttiauxella spp. bacterium, expressed in a Trichoderma reesei fungus) was produced by Danisco Animal Nutrition, DuPont Industrial Biosciences (Marlborough, UK), at 1000 phytase units (FTU)/kg of final feed. One FTU is defined as the quantity of enzyme required to liberate $1 \mu \mathrm{mol}$ of inorganic $\mathrm{P} / \mathrm{min}$, at $\mathrm{pH} 5.5$, from an excess of $15 \mu \mathrm{M}$ sodium phytate at $37{ }^{\circ} \mathrm{C}$ (International Union of Biochemistry and Molecular Biology, 1992). The commercial powdered enzyme was added at $200 \mathrm{~g} / \mathrm{to} 1000 \mathrm{FTU} / \mathrm{kg}$ feed (on top), as recommended by the manufacturer. The chemical compositions of diets are presented in Table 1.

The feeding programme was divided into three feeding phases: starter (days 1-10), grower (days 1122), and finisher (days 23-42). Diets for each feeding phase were formulated to be isocaloric, isonitrogenous, with similar content of total lysine, total sulfur amino acids (TSAA) (methionine + cysteine), calcium and available phosphorous, and to meet or exceed breeder guidelines (Cobb Vantress Europe Ltd, UK). Feed (in mash form) and water were provided ad libitum throughout the trial. Samples of ingredients and feed were analysed in duplicate for content of dry matter, crude protein $(\mathrm{N} \times 6.25)$, ether extract and ash, using standard procedures according to the methods of the Commission Regulation (EC) no. 152 (OJEU, 2009). The contents of neutral detergent fibre (NDF) and acid detergent fibre (ADF) were determined using a Fibertec apparatus (automatic system Foss Tecator, Höganäs, Sweden). Carbohydrate content was estimated as nitrogen-free extract (NFE). Amino acids (AA) (excluding tryptophan, which was not determined) were analysed using a Thermo Scientific Surveyor Plus HPLC System (Thermo Fisher Scientific, MA, USA), according to the conditions described by Ciurescu \& Pană (2017). Data are from the analysis carried out by the chemistry laboratory of National Research Development Institute for Biology and Animal Nutrition in Balotești, Romania. 
Table 1 Ingredients and nutrient composition (as-dry basis) of diets used in the study

\begin{tabular}{|c|c|c|c|c|c|c|c|c|c|c|c|c|}
\hline \multirow{3}{*}{ Diets } & \multicolumn{12}{|c|}{ Low-fibre SFM levels as a substitute for SBM (\%) } \\
\hline & \multicolumn{4}{|c|}{ Starter diets (0-10 days) } & \multicolumn{4}{|c|}{ Grower diets (11-22 days) } & \multicolumn{4}{|c|}{ Finisher diets (23-42 days) } \\
\hline & 0 & 25 & 50 & 75 & 0 & 25 & 50 & 75 & 0 & 25 & 50 & 75 \\
\hline \multicolumn{13}{|l|}{ Ingredients (\%) } \\
\hline Corn & 57.62 & 58.64 & 58.62 & 58.76 & 67.43 & 68.24 & 67.94 & 67.68 & 68.54 & 69.05 & 68.72 & 68.41 \\
\hline $\begin{array}{l}\text { Soybean meal } \\
\text { (CP 46\%) }\end{array}$ & 31.40 & 22.50 & 15.00 & 7.50 & 22.0 & 15.00 & 10.00 & 5.00 & 21.50 & 15.00 & 10.00 & 5.00 \\
\hline $\begin{array}{l}\text { LF-SFM (CP } \\
44 \%)\end{array}$ & 0.0 & 7.50 & 15.00 & 22.50 & 0.0 & 5.00 & 10.00 & 15.00 & 0.0 & 5.00 & 10.00 & 15.00 \\
\hline $\begin{array}{l}\text { Corn gluten meal } \\
(\text { CP 62\%) }\end{array}$ & 4.00 & 4.60 & 4.50 & 4.30 & 4.00 & 5.60 & 6.00 & 6.20 & 3.00 & 4.20 & 4.50 & 4.80 \\
\hline Sunflower oil & 2.00 & 1.70 & 1.70 & 1.70 & 1.50 & 1.10 & 1.00 & 1.00 & 2.50 & 2.20 & 2.20 & 2.20 \\
\hline $\begin{array}{l}\text { Monocalcium } \\
\text { phosphate }\end{array}$ & 1.67 & 1.56 & $1.5,3$ & 1.45 & 1.56 & 1.50 & 1.45 & 1.42 & 1.38 & 1.34 & 1.28 & 1.25 \\
\hline $\begin{array}{l}\text { Calcium } \\
\text { carbonate }\end{array}$ & 1.45 & 1.46 & $1.4,6$ & 1.46 & 1.39 & 1.42 & 1.42 & 1.42 & 1.25 & 1.28 & 1.29 & 1.27 \\
\hline Salt & 0.28 & 0.28 & $0.2,8$ & 0.28 & 0.28 & 0.28 & 0.28 & 0.28 & 0.28 & 0.28 & 0.28 & 0.28 \\
\hline L-Lysine (78\%) & 0.25 & 0.45 & 0.60 & 0.75 & 0.42 & 0.56 & 0.63 & 0.72 & 0.27 & 0.39 & 0.48 & 0.55 \\
\hline $\begin{array}{l}\text { Dl-Methionine } \\
(99 \%)\end{array}$ & 0.25 & 0.23 & 0.23 & 0.22 & 0.24 & 0.22 & 0.20 & 0.20 & 0.20 & 0.18 & 0.17 & 0.16 \\
\hline Choline chloride & 0.08 & 0.08 & 0.08 & 0.08 & 0.08 & 0.08 & 0.08 & 0.08 & 0.08 & 0.08 & 0.08 & 0.08 \\
\hline Premix vit-min ${ }^{1}$ & 1.0 & 1.0 & 1.0 & 1.0 & 1.0 & 1.0 & 1.0 & 1.0 & 1.0 & 1.0 & 1.0 & 1.0 \\
\hline Phytase $^{2}$ & $-1++^{3}$ & $-/+$ & $-/+$ & $-/+$ & $-1+$ & $-1+$ & $-/+$ & $-1+$ & $-1+$ & $-1+$ & $-1+$ & $-/+$ \\
\hline \multicolumn{13}{|c|}{ Calculated composition } \\
\hline $\mathrm{ME}(\mathrm{MJ} / \mathrm{kg})$ & 12.69 & 12.69 & 12.69 & 12.70 & 12.99 & 13.00 & 12.98 & 12.99 & 13.28 & 13.28 & 13.29 & 13.30 \\
\hline Crude protein & 22.25 & 22.24 & 22.31 & 22.32 & 19.02 & 19.03 & 19.08 & 19.04 & 18.06 & 18.04 & 18.06 & 18.05 \\
\hline Lysine, total & 1.30 & 1.30 & 1.30 & 1.30 & 1.19 & 1.19 & 1.19 & 1.19 & 1.05 & 1.05 & 1.05 & 1.05 \\
\hline Lysine, digestible & 1.21 & 1.17 & 1.16 & 1.17 & 1.11 & 1.11 & 1.10 & 1.10 & 1.00 & 0.99 & 0.99 & 0.99 \\
\hline TSAA & 0.98 & 0.97 & 0.98 & 0.97 & 0.89 & 0.89 & 0.88 & 0.89 & 0.82 & 0.82 & 0.82 & 0.82 \\
\hline Calcium & 0.90 & 0.90 & 0.90 & 0.90 & 0.84 & 0.84 & 0.84 & 0.84 & 0.76 & 0.76 & 0.76 & 0.76 \\
\hline $\begin{array}{l}\text { Available } \\
\text { phosphorous }\end{array}$ & 0.45 & 0.44 & 0.45 & 0.45 & 0.42 & 0.42 & 0.42 & 0.42 & 0.38 & 0.38 & 0.38 & 0.38 \\
\hline Crude fat & 4.92 & 4.76 & 4.89 & 4.97 & 4.67 & 4.40 & 4.37 & 4.43 & 5.67 & 5.48 & 5.54 & 5.61 \\
\hline Crude fibre & 2.80 & 3.30 & 3.84 & 4.38 & 2.53 & 3.07 & 3.67 & 4.27 & 2.51 & 3.06 & 3.66 & 4.26 \\
\hline \multicolumn{13}{|c|}{ Analysed composition } \\
\hline Dry matter & 88.2 & 87.6 & 88.7 & 89.2 & 86.5 & 87.9 & 88.6 & 89.0 & 86.2 & 87.4 & 87.7 & 87.6 \\
\hline Crude protein & 22.12 & 22.21 & 22.77 & 22.65 & 19.27 & 19.35 & 19.42 & 19.33 & 18.32 & 18.39 & 18.45 & 18.43 \\
\hline Crude fat & 4.88 & 4.75 & 4.82 & 4.94 & 4.78 & 4.25 & 4.23 & 4.30 & 5.56 & 5.34 & 5.69 & 5.72 \\
\hline Crude fibre & 3.10 & 3.87 & 3.93 & 4.77 & 2.76 & 3.45 & 3.92 & 4.53 & 2.67 & 3.41 & 3.88 & 4.37 \\
\hline
\end{tabular}

\footnotetext{
${ }^{1}$ Supplied per kg diet: $4.47 \mathrm{mg}$ retinyl acetate, $0.12 \mathrm{mg}$ cholecalciferol, $80 \mathrm{mg} \mathrm{DL}$ - $\alpha$-tocopheryl acetate, $4 \mathrm{mg}$ menadione sodium bisulphite, $4 \mathrm{mg}$ thiamine mononitrate, $9 \mathrm{mg}$ riboflavin, $4 \mathrm{mg}$ pyridoxine- $\mathrm{HCl}, 0.020 \mathrm{mg}$ cyanocobalamin, $15 \mathrm{mg}$ Ca-panthotenate, $60 \mathrm{mg}$ niacin, $2 \mathrm{mg}$ folic acid, $100 \mathrm{mg} \mathrm{Mn}, 100 \mathrm{mg} \mathrm{Zn,} 40 \mathrm{mg} \mathrm{Fe}, 15 \mathrm{mg} \mathrm{Cu}, 1.0 \mathrm{mg} \mathrm{I}, 0.30 \mathrm{mg} \mathrm{Se}, 0.25$ mg Co.

${ }_{3}^{2}$ Phytase added to diets at 0 or $0.2 \mathrm{~g} / \mathrm{kg}(1000 \mathrm{FTU} / \mathrm{kg}$ feed)

3 - = enzyme not included in the diet; + = enzyme included in the diet

ME: metabolizable energy; TSAA: total sulfur amino acids
}

On days 11,23 , and 42 , the birds and residual feed were weighed using a Kern scale (PCB 6000-0, Balingen, Germany) and the feed intake (FI), body weight gain (BWG), and feed conversion ratio (FCR) were calculated. Dead birds were weighed and removed, and the percentage mortality was calculated. At days 42 old, three broiler chickens per replicate pen (nearest to the average weight of the same pen) were selected, fasted for three hours with water being provided ad libitum, and killed by severing the right carotid artery and jugular vein. Slaughtered birds were weighed and their internal organs, including gizzard, liver, pancreas, and spleen, were removed, cleaned of adhering tissues, and weighed individually. The small intestines (duodenum, jejunum, and ileum) were also weighed and recorded. The cecum was quickly dissected, and the fresh contents were gently squeezed and carefully collected in $25 \mathrm{ml}$ sterilized tubes. The cecal digesta 
$\mathrm{pH}$ was measured (mean of three readings) with a portable pH-meter (WTW pH 3310, WTW GmbH, Weilheim, Germany). Carcasses, abdominal fat, and digestive organs were weighed, excluding head, neck, and feet. Carcass yield and relative weights of digestive organs were expressed as percentages of live bodyweight.

At day 42, blood samples were collected via the brachial vein of two broiler chickens per replicate pen, chosen randomly, into sterilized tubes (Vacutest Kima, 4ml, Italy) with heparin as an anticoagulant. The tubes were centrifuged at $3000 \mathrm{rpm}$ for 15 minutes (iFuge D06, Neuation Technologies Pvt. Ltd, India). The resultant plasma was transferred to Eppendorf tubes and stored at $-20^{\circ} \mathrm{C}$ until further analyses. Total protein (T-Pro), albumin (Alb), total bilirubin (T-Bil), creatinine (Cre), urea (BUN), uric acid (UA), total cholesterol (TCho), triglycerides (TG), high-density lipoproteins cholesterol (HDL-C), calcium (Ca), magnesium (Mg), inorganic phosphorus (IP), alanine aminotransferase (ALT/GPT), aspartate aminotransferase (AST/GOT) and gamma-glutamyl-transferase (GGT) were determined with an automated biochemical analyser (dry chemistry system Spotchem EZ, SP- 4430 model; ARKRAY Global Business Inc., Kyoto, Japan) using the respective Arkray Diagnostic Kits.

Data were analysed with the general linear model (GLM) procedure of SPSS 20.0 software (2011). The statistical model included the effects of LF-SFM level, phytase addition, and their interaction. For growth performance (BWG, FI, and FCR), each pen was regarded as the experimental unit $(n=5)$. For other variables (carcass traits and plasma profiles) each sample was considered the experimental unit. Effects were considered statistically significant at $P<0.05$. Probability values between 0.05 and 0.10 were considered trends. Post hoc multiple comparisons were performed by Tukey`s test.

\section{Results and discussion}

The nutrient composition and amino acids profile of LF-SFM that were used for this study are shown in Tables 2 and 3. LF-SFM was found to contain an appreciable amount of crude protein compared with SBM (44-48.5\%) as recorded by NRC (1994). In comparison with SBM, LF-SFM had lower metabolizable energy (7.10 vs $9.33 \mathrm{MJ}$ ) and threefold higher fibre content (11.31 vs $3.9 \%)$.

Table 2 Nutrient composition and metabolizable energy of low-fibre sunflower meal, as fed basis $(n=2)$

\begin{tabular}{lccccccccccc}
\hline Nutrients & DM & CP & EE & Fibre & Ash & NFE & NDF & ADF & ME (MJ) & Ca & P \\
\hline LF-SFM & 96.39 & 43.36 & 0.68 & 11.31 & 7.96 & 33.08 & 24.18 & 12.71 & 7.10 & 0.44 & 1.59
\end{tabular}

LF-SFM: low-fibre sunflower meal; DM: dry matter; CP: crude protein; EE: ether extract; NFE: nitrogen free extract; NDF: neutral detergent fibre; ADF: acid detergent fibre; ME: metabolizable energy; Ca: calcium; P: phosphorous

The metabolizable energy (ME) content of LF-SFM was estimated based on the following equation (NRC, 1994):

$$
M E=6.28(D M)-6.28(a s h)+25.38(C P)+62.62(E E),
$$

Where: DM, CP, and EE are dry matter, crude protein, and ether extract, percentage of SFM, respectively.

All essential AA, except the lysine (3.7-4 \% of the protein) were present in excessive amounts. LFSFM had higher sulfur-containing amino acids (methionine and cysteine 2\%), compared with the requirements of broilers in the starter phase.

Table 3 Amino acid profile $(\mathrm{g} / 100 \mathrm{~g})$ of low-fibre sunflower meal

\begin{tabular}{lccc}
\hline AA & LF-SFM & AA & LF-SFM \\
\hline Lysine & 1.636 & Phenylalanine & 2.359 \\
Methionine & 0.715 & Tyrosine & 1.192 \\
Cystine & 0.659 & Serine & 2.592 \\
Threonine & 2.923 & Glycine & 2.650 \\
Leucine & 3.322 & Alanine & 2.326 \\
\hline
\end{tabular}




\begin{tabular}{llll}
\hline Arginine & 4.077 & Aspartic acid & 4.701 \\
Isoleucine & 1.905 & Glutamic acid & 9.991 \\
Valine & 1.958 & & \\
\hline
\end{tabular}

AA: amino acids; LF-SFM: low-fibre sunflower meal

The effects of LF-SFM level, phytase supplementation and interaction between level and enzyme on the performance of broiler chicks are presented in Table 4 . Mortality was low $(<2.5 \%)$ and unrelated to treatment. There was no significant effect $(P>0.05)$ between the interaction of the main factors $(\mathrm{LF}-\mathrm{SFM} \times$ phytase) on BWG, FI, and FCR of broiler during the starter, grower and finisher phases and the overall period. In the first period of the trial (days 1-10), the results revealed that the broilers fed diets containing LFSFM at $25 \%$ or $50 \%$ instead of SBM had comparable BWG. However, increasing LF-SFM in diets from 50 to $75 \%$ significantly $(P<0.001)$ decreased BWG.

$\mathrm{FI}$ and FCR were not significantly $(P>0.05)$ affected by the various LF-SFM inclusion levels. During the grower period (days 11-22), the diets with LF-SFM levels up to $25 \%$ generated BWG that was comparable with a diet containing SBM. Conversely, higher levels of LF-SFM (50\% and $75 \%)$ recorded the lowest value of BWG $(P<0.001)$ and consequently impaired FCR $(P=0.043)$ in comparison with other levels. During the finisher phase (days 21-42), high inclusion levels of SFM (50\% and 75\%) posed the same problems, so resulted in a reduction of BWG $(P<0.001)$ and impaired FCR $(P=0.023)$, but had no effect on $\mathrm{FI}(P>0.05)$. The addition of phytase in the diets had no impact on $\mathrm{FI}(P>0.05)$, and tended $(P=0.067)$ to impair BWG and FCR $(P=0.075)$. Over the entire feeding period the poorest values of BWG $(P<0.001)$ and FCR $(P=0.004)$ were observed in chicks fed diets that contained $50 \%$ or $75 \%$ LF-SFM, whether supplemented with the enzyme or not. The addition of $0.2 \mathrm{~g}$ microbial phytase $/ \mathrm{kg}$ diets was not effective in improving BWG, FCR, or FI $(P>0.05)$.

There are no reports about the use of LF-SFM in broiler chicken diets. Some studies are related to other poultry species. Most of them have shown that up to $15 \%$ and $18 \%$ processed SFM have been used with success in laying hens (Laudadio et al., 2014a) and turkey diets (Laudadio et al., 2014), respectively. Earlier studies that investigated the effect of the use of SFM as a replacement for SBM showed inconsistent results. The findings of the current study are in line with the results of Mandal et al. (2006), Abdelrahman \& Saleh (2007) and Peric et al. (2010), who found that the inclusion SFM in broiler diets decreased growth performance in terms of poor feed efficiency and growth rate. On the other hand, in other studies, the inclusion of SFM up to 20\% (Tavernari et al., 2008) and even higher levels (Rama Rao et al., 2006; Mushtaq et al., 2009) did not have adverse effects on BW or BWG. Senkoylu et al. (2006) did not observe any effect on broiler performance when up to $28 \%$ SFM was included in the feed. However, those authors used the residue of SFM from cold pressing $(32.3 \% \mathrm{CP}$ and $18.78 \% \mathrm{EE})$. In the same context, Alagawany et al. (2017) reported that increasing SFM level in the diet up to 50\% to replace SBM improved performance traits (including BW, BWG, and FCR). This difference may be attributed to the quality or level of the SFM processing or variety of the birds.

There were no significant differences among the treatments because of the interaction effects between dietary LF-SFM level and phytase supplementation on growth performance (Table 4). Phytase addition had no beneficial effects on performance traits. The poorest values $(1,670 \mathrm{~g})$ of BWG and 2.03 (g feed/g gain) of FCR were achieved by broilers fed LF-SFM supplemented with exogenous phytase in the finishing period. This finding suggests that the use of Trichoderma reesei-derived phytase was not efficacious in releasing phytate P from LF-SFM. In this context, Adeola \& Cowieson (2011), Ranvindran (2013), and Dersjant-Li et al. (2015) noted that the response of chickens to a phytase might be affected by various factors, such as the substrate (nutrients and antinutrients in the ingredients used in feed formulations) and enzyme origin (fungal vs. bacterial vs. yeast), and the conditions in the gastrointestinal tract, such as moisture content, temperature and $\mathrm{pH}$. 
Table 4 Dietary low-fibre sunflower meal level and phytase addition on growth performance of broiler chickens

\begin{tabular}{|c|c|c|c|c|c|c|c|c|c|c|c|c|c|c|}
\hline \multirow{2}{*}{ Treatments } & \multirow{2}{*}{$\begin{array}{l}\text { LF-SFM } \\
(\%)\end{array}$} & \multirow{2}{*}{$\begin{array}{l}\text { Phytase } \\
\text { (g/ kg diet) }\end{array}$} & \multicolumn{3}{|c|}{$1-10$ days } & \multicolumn{3}{|c|}{ 11-22 days } & \multicolumn{3}{|c|}{ 23-42 days } & \multicolumn{3}{|c|}{1 to 42 days } \\
\hline & & & BWG (g) & $\begin{array}{l}\mathrm{FI} \\
(\mathrm{g})\end{array}$ & $\begin{array}{l}\text { FCR } \\
(\mathrm{g} / \mathrm{g})\end{array}$ & $\begin{array}{c}\text { BWG } \\
(\mathrm{g})\end{array}$ & $\begin{array}{l}\mathrm{FI} \\
(\mathrm{g})\end{array}$ & $\begin{array}{l}\text { FCR } \\
(\mathrm{g} / \mathrm{g})\end{array}$ & $\begin{array}{l}\text { BWG } \\
(\mathrm{g})\end{array}$ & $\begin{array}{l}\mathrm{FI} \\
(\mathrm{g})\end{array}$ & $\begin{array}{l}\text { FCR } \\
(\mathrm{g} / \mathrm{g})\end{array}$ & $\begin{array}{l}\text { BWG } \\
(\mathrm{g})\end{array}$ & $\begin{array}{l}\mathrm{FI} \\
(\mathrm{g})\end{array}$ & $\begin{array}{l}\text { FCR } \\
(\mathrm{g} / \mathrm{g})\end{array}$ \\
\hline $1^{2}$ & 0 & 0 & 228 & 368 & 1.61 & 670 & 1,021 & 1.52 & 1,793 & 3,490 & 1.95 & 2,692 & 4,878 & 1.81 \\
\hline 2 & 25 & 0 & 226 & 366 & 1.62 & 659 & 1,004 & 1.52 & 1,790 & 3,481 & 1.94 & 2,675 & 4,851 & 1.81 \\
\hline 3 & 50 & 0 & 221 & 363 & 1.64 & 622 & 974 & 1.57 & 1,673 & 3,378 & 2.02 & 2,516 & 4,714 & 1.87 \\
\hline 4 & 75 & 0 & 216 & 357 & 1.65 & 619 & 972 & 1.57 & 1,662 & 3,360 & 2.02 & 2,497 & 4,689 & 1.88 \\
\hline 5 & 0 & 0.2 & 227 & 370 & 1.63 & 673 & 1,025 & 1.52 & 1,755 & 3,443 & 1.96 & 2,656 & 4,840 & 1.82 \\
\hline 6 & 25 & 0.2 & 224 & 364 & 1.63 & 652 & 1,006 & 1.54 & 1,738 & 3,419 & 1.97 & 2,615 & 4,788 & 1.83 \\
\hline 7 & 50 & 0.2 & 223 & 367 & 1.65 & 644 & 998 & 1.55 & 1,605 & 3,341 & 2.08 & 2,472 & 4,705 & 1.90 \\
\hline 8 & 75 & 0.2 & 217 & 359 & 1.65 & 639 & 993 & 1.55 & 1,579 & 3,346 & 2.12 & 2,435 & 4,697 & 1.93 \\
\hline SEM & & & 1.70 & 4.40 & 0.01 & 3.70 & 10.40 & 0.01 & 11.30 & 17.40 & 0.01 & 13.40 & 35.60 & 0.01 \\
\hline \multicolumn{15}{|l|}{ Main effects ${ }^{3}$} \\
\hline \multicolumn{15}{|l|}{ Level (L) } \\
\hline 0 & & & $228^{a}$ & 369 & 1.62 & $672^{a}$ & 1,024 & $1.52^{\mathrm{b}}$ & $1,774^{\mathrm{a}}$ & 3,466 & $1.96^{\mathrm{b}}$ & $2,674^{\mathrm{a}}$ & 4,858 & $1.82^{b}$ \\
\hline 25 & & & $225^{\mathrm{ab}}$ & 365 & 1.63 & $656^{\mathrm{a}}$ & 1,005 & $1.53^{\mathrm{ab}}$ & $1,764^{\mathrm{a}}$ & 3,450 & $1.96^{\mathrm{b}}$ & $2,645^{\mathrm{a}}$ & 4,820 & $1.82^{\mathrm{b}}$ \\
\hline 50 & & & $222^{b c}$ & 364 & 1.65 & $634^{b}$ & 986 & $1.55^{\mathrm{a}}$ & $1,625^{b}$ & 3,361 & $2.07^{\mathrm{a}}$ & $2,480^{b}$ & 4,710 & $1.90^{\mathrm{a}}$ \\
\hline 75 & & & $217^{\mathrm{c}}$ & 358 & 1.65 & $630^{\mathrm{b}}$ & 983 & $1.56^{\mathrm{a}}$ & $1,621^{\mathrm{b}}$ & 3,353 & $2.07^{\mathrm{a}}$ & $2,466^{\mathrm{b}}$ & 4,693 & $1.90^{\mathrm{a}}$ \\
\hline \multicolumn{15}{|l|}{ Phytase (PHY) } \\
\hline No & & & 224 & 364 & 1.63 & 644 & 993 & 1.54 & 1,730 & 3,427 & 1.98 & 2,595 & 4,783 & 1.85 \\
\hline Yes & & & 223 & 365 & 1.64 & 652 & 1,006 & 1.54 & 1,670 & 3,388 & 2.03 & 2,538 & 4,759 & 1.88 \\
\hline \multicolumn{15}{|l|}{ P-value } \\
\hline$L$ effect & & & $<0.0001$ & 0.178 & 0.442 & $<0.0001$ & 0.121 & 0.043 & $<0.0001$ & 0.340 & 0.023 & $<0.0001$ & 0.127 & 0.004 \\
\hline PHY effect & & & 0.634 & 0.924 & 0.754 & 0.527 & 0.381 & 0.929 & $0.067^{\top}$ & 0.545 & $0.075^{\top}$ & 0.348 & 0.432 & 0.534 \\
\hline L X PHY effect & & & 0.826 & 0.887 & 0.927 & 0.898 & 0.927 & 0.929 & 0.924 & 0.765 & 0.768 & 0.924 & 0.688 & 0.670 \\
\hline
\end{tabular}

a,b,c Columns means with different superscripts differ significantly at $P<0.05$ ${ }^{1}$ Axtra $\circledast$ PHY 5000 L (1000 FTU/kg feed)

${ }^{2}$ Control group

${ }^{3}$ Data were analysed as $4 \times 2$ factorial arrangement

LF-SFM: low-fibre sunflower meal 
Table 5 Means of dietary low-fibre sunflower meal level and phytase addition on carcass traits of broiler chickens ${ }^{1}$

\begin{tabular}{|c|c|c|c|c|c|c|c|c|c|c|c|}
\hline \multirow[t]{2}{*}{ Treatments } & \multirow{2}{*}{$\begin{array}{l}\text { LF-SFM } \\
(\%)\end{array}$} & \multirow{2}{*}{$\begin{array}{c}\text { Phytase }^{2} \\
(\mathrm{~g} / \mathrm{kg})\end{array}$} & \multirow{2}{*}{ Carcass $^{5}$} & \multirow{2}{*}{ Breast $^{6}$} & \multirow{2}{*}{ Abdominal fat ${ }^{6}$} & \multicolumn{5}{|c|}{ Digestive organs weight $^{7}$} & \multirow{2}{*}{$\begin{array}{c}\text { Ceca } \\
\mathrm{pH}\end{array}$} \\
\hline & & & & & & Gizzard & Liver & Pancreas & Spleen & Small intestine & \\
\hline $1^{3}$ & 0 & 0 & 72.9 & 29.2 & 1.57 & 2.19 & 2.60 & 0.30 & 0.09 & 3.03 & 6.56 \\
\hline 2 & 25 & 0 & 72.4 & 28.7 & 1.46 & 2.16 & 2.53 & 0.29 & 0.11 & 3.10 & 6.62 \\
\hline 3 & 50 & 0 & 71.8 & 28.6 & 1.28 & 2.22 & 2.62 & 0.25 & 0.10 & 3.17 & 6.59 \\
\hline 4 & 75 & 0 & 72.6 & 28.9 & 1.22 & 2.28 & 2.59 & 0.31 & 0.11 & 3.21 & 6.64 \\
\hline 5 & 0 & 0.2 & 71.5 & 28.4 & 1.55 & 2.14 & 2.47 & 0.28 & 0.09 & 3.09 & 6.55 \\
\hline 6 & 25 & 0.2 & 70.9 & 28.8 & 1.42 & 2.17 & 2.59 & 0.29 & 0.10 & 2.90 & 6.50 \\
\hline 7 & 50 & 0.2 & 70.7 & 28.5 & 1.31 & 2.25 & 2.61 & 0.30 & 0.08 & 3.11 & 6.60 \\
\hline 8 & 75 & 0.2 & 71.4 & 28.3 & 1.24 & 2.17 & 2.52 & 0.26 & 0.11 & 3.14 & 6.57 \\
\hline SEM & & & 1.10 & 0.62 & 0.09 & 0.24 & 0.19 & 0.04 & 0.01 & 0.33 & 0.22 \\
\hline \multicolumn{12}{|l|}{ Main effects ${ }^{4}$} \\
\hline \multicolumn{12}{|l|}{ Level (L) } \\
\hline 0 & & & 72.2 & 28.8 & $1.56^{\mathrm{a}}$ & 2.17 & 2.54 & 0.29 & 0.09 & $3.06^{b}$ & 6.55 \\
\hline 25 & & & 71.7 & 28.7 & $1.44^{\mathrm{b}}$ & 2.16 & 2.56 & 0.29 & 0.11 & $2.99^{b}$ & 6.56 \\
\hline 50 & & & 71.4 & 28.7 & $1.29^{\mathrm{bc}}$ & 2.20 & 2.61 & 0.28 & 0.09 & $3.14^{\mathrm{a}}$ & 6.60 \\
\hline 75 & & & 72.0 & 28.6 & $1.23^{\mathrm{C}}$ & 2.23 & 2.56 & 0.29 & 0.11 & $3.18^{\mathrm{a}}$ & 6.61 \\
\hline \multicolumn{12}{|l|}{ Phytase (PHY) } \\
\hline No & & & 72.4 & 28.8 & 1.38 & 2.21 & 2.59 & 0.29 & 0.10 & 3.13 & 6.60 \\
\hline Yes & & & 71.2 & 28.5 & 1.38 & 2.18 & 2.55 & 0.28 & 0.09 & 3.06 & 6.56 \\
\hline \multicolumn{12}{|l|}{$P$-value } \\
\hline$L$ effect & & & 0.467 & 0.543 & $<0.001$ & $0.096^{\top}$ & 0.215 & 0.494 & 0.510 & $<0.001$ & 0.583 \\
\hline PHY effect & & & 0.332 & 0.657 & 0.767 & 0.443 & 0.384 & 0.786 & 0.578 & 0.334 & 0.625 \\
\hline L x PHY effect & & & 0.682 & 0.951 & 0.546 & 0.567 & 0.333 & 0.624 & 0.862 & 0.476 & 0.563 \\
\hline
\end{tabular}

${ }^{a, b, c}$ Columns means with different superscripts differ significantly at $P<0.05$

${ }^{1}$ Data are means of 15 broilers for each treatment

${ }^{2}$ Axtra ${ }^{2}$ PHY 5000 L (1000 FTU/kg feed)

${ }^{3}$ Control group

${ }^{4}$ Data were analysed as $4 \times 2$ factorial arrangement

${ }^{5}$ Represents as weight $(\mathrm{g})$ of without head, neck and feet carcass as $100 \mathrm{~g}$ of live body weight

${ }^{6}$ Calculated as weight $(\mathrm{g})$ of carcass characteristics to $100 \mathrm{~g}$ of live body weight

${ }^{7}$ Represents as weight (g) of organ weights as $100 \mathrm{~g}$ of live body weight 
Table 6 Means of dietary low-fibre sunflower meal levels and phytase addition on plasma metabolic profile of broiler chickens ${ }^{1}$

\begin{tabular}{|c|c|c|c|c|c|c|c|c|c|c|c|c|c|c|c|c|c|}
\hline \multirow{2}{*}{$\begin{array}{l}\text { Treat- } \\
\text { ments }\end{array}$} & \multirow{2}{*}{$\begin{array}{l}\text { LF- } \\
\text { SFM } \\
(\%)\end{array}$} & \multirow{2}{*}{$\begin{array}{l}\text { Phy }^{2} \\
(g / k g)\end{array}$} & \multicolumn{3}{|c|}{ Energy profile } & \multicolumn{6}{|c|}{ Protein profile } & \multicolumn{3}{|c|}{ Mineral profile } & \multicolumn{3}{|c|}{ Enzyme profile } \\
\hline & & & $\begin{array}{l}\text { T-Cho } \\
\mathrm{mg} / \mathrm{dL}\end{array}$ & $\begin{array}{c}\text { HDL-C } \\
\text { U/L }\end{array}$ & $\begin{array}{c}\mathrm{TG} \\
\mathrm{mg} / \mathrm{dL}\end{array}$ & $\begin{array}{l}\text { T-Pro } \\
\text { g/dL }\end{array}$ & $\begin{array}{l}\text { Alb } \\
\mathrm{g} / \mathrm{dL}\end{array}$ & $\begin{array}{c}\text { T-Bil } \\
\mathrm{mg} / \mathrm{dL}\end{array}$ & $\begin{array}{c}\text { Cre } \\
\mathrm{mg} / \mathrm{dL}\end{array}$ & $\begin{array}{c}\mathrm{UA} \\
\mathrm{mg} / \mathrm{dL}\end{array}$ & $\begin{array}{l}\text { BUN } \\
\mathrm{mg} / \mathrm{dL}\end{array}$ & $\begin{array}{c}\mathrm{Ca} \\
\mathrm{mg} / \mathrm{dL}\end{array}$ & $\begin{array}{c}\mathrm{IP} \\
\mathrm{mg} / \mathrm{dL}\end{array}$ & $\begin{array}{c}\mathrm{Mg} \\
\mathrm{mg} / \mathrm{dL}\end{array}$ & $\begin{array}{c}\text { ALT/GPT } \\
\text { IU/L }\end{array}$ & $\begin{array}{c}\text { AST/GOT } \\
\text { IU/L }\end{array}$ & $\begin{array}{l}\text { GGT } \\
\text { U/L }\end{array}$ \\
\hline $1^{3}$ & 0 & 0 & 115.2 & 97.8 & 55.2 & 2.04 & 0.78 & 0.12 & 0.56 & 4.62 & 3.20 & 12.74 & 6.60 & 1.86 & 9.4 & 278.4 & 47.8 \\
\hline 2 & 25 & 0 & 133.0 & 119.2 & 47.0 & 2.34 & 0.84 & 0.16 & 0.58 & 5.06 & 2.00 & 12.96 & 6.82 & 1.98 & 9.4 & 332.4 & 46.0 \\
\hline 3 & 50 & 0 & 109.0 & 83.6 & 84.4 & 2.14 & 0.68 & 0.16 & 0.58 & 4.14 & 2.00 & 12.36 & 6.80 & 1.98 & 8.6 & 272.6 & 42.8 \\
\hline 4 & 75 & 0 & 111.4 & 82.4 & 78.0 & 2.28 & 0.82 & 0.14 & 0.60 & 4.74 & 2.00 & 12.66 & 6.84 & 2.02 & 7.6 & 234.6 & 46.0 \\
\hline 5 & 0 & 0.2 & 108.4 & 89.8 & 31.8 & 2.08 & 0.76 & 0.14 & 0.64 & 4.88 & 2.00 & 12.24 & 6.24 & 2.12 & 7.6 & 236.6 & 39.2 \\
\hline 6 & 25 & 0.2 & 131.6 & 131.8 & 55.8 & 2.34 & 0.98 & 0.16 & 0.60 & 5.08 & 2.00 & 12.72 & 7.18 & 2.02 & 10.4 & 322.8 & 46.8 \\
\hline 7 & 50 & 0.2 & 122.0 & 110.2 & 52.4 & 2.30 & 0.80 & 0.18 & 0.58 & 4.58 & 2.00 & 12.90 & 6.82 & 2.08 & 7.0 & 273.6 & 42.6 \\
\hline 8 & 75 & 0.2 & 122.4 & 115.2 & 76.6 & 2.18 & 0.74 & 0.14 & 0.66 & 4.68 & 2.00 & 13.18 & 7.68 & 2.06 & 7.6 & 301.4 & 46.6 \\
\hline SEM & & & 5.56 & 8.57 & 13.89 & 0.12 & 0.07 & 0.03 & 0.03 & 0.56 & 0.26 & 0.44 & 0.30 & 0.09 & 1.45 & 57.98 & 3.31 \\
\hline \multicolumn{18}{|c|}{ Main effects ${ }^{4}$} \\
\hline \multicolumn{18}{|c|}{ Level (L) } \\
\hline 0 & & & $111.80^{b}$ & $93.80^{b}$ & $43.5^{\top}$ & 2.06 & 0.77 & 0.13 & 0.60 & 4.75 & $2.60^{\top}$ & 12.49 & $6.42^{\top}$ & 1.99 & 8.5 & 257.5 & 43.5 \\
\hline 25 & & & $132.30^{\mathrm{a}}$ & $125.50^{\mathrm{a}}$ & 51.4 & 2.34 & $0.91^{\top}$ & 0.16 & 0.59 & 5.07 & 2.00 & 12.84 & 7.00 & 2.00 & 9.9 & 327.6 & 46.4 \\
\hline 50 & & & $115.50^{\mathrm{b}}$ & $96.90^{\mathrm{b}}$ & 68.4 & 2.22 & $0.74^{\top}$ & 0.17 & 0.58 & 4.36 & 2.00 & 12.63 & 6.81 & 2.03 & 7.8 & 273.1 & 42.7 \\
\hline 75 & & & $116.90^{\mathrm{b}}$ & $98.80^{\mathrm{b}}$ & $77.3^{\top}$ & 2.23 & 0.78 & 0.14 & 0.63 & 4.71 & 2.00 & 12.92 & $7.26^{\top}$ & 2.04 & 7.6 & 268.0 & 46.3 \\
\hline \multicolumn{18}{|c|}{ Phytase (PHY) } \\
\hline No & & & 117.15 & $95.75^{\mathrm{b}}$ & 66.15 & 2.20 & 0.78 & 0.15 & 0.58 & 4.64 & 2.30 & 12.68 & 6.76 & 1.96 & 8.75 & 279.5 & 45.65 \\
\hline Yes & & & 121.10 & $111.75^{\mathrm{a}}$ & 54.15 & 2.22 & 0.82 & 0.16 & 0.62 & 4.80 & 2.00 & 12.76 & 6.98 & $2.07^{\top}$ & 8.15 & 283.6 & 43.80 \\
\hline \multicolumn{18}{|c|}{$P$-value } \\
\hline$L$ effect & & & 0.004 & 0.003 & $0.080^{\top}$ & 0.171 & $0.096^{\top}$ & 0.429 & 0.532 & 0.661 & $0.064^{\top}$ & 0.750 & $0.057^{\top}$ & 0.932 & 0.390 & 0.629 & 0.582 \\
\hline PHY eff & & & 0.323 & 0.013 & 0.231 & 0.774 & 0.426 & 0.648 & 0.119 & 0.680 & 0.112 & 0.797 & 0.319 & $0.088^{\top}$ & 0.561 & 0.921 & 0.435 \\
\hline $\mathrm{L} \times \mathrm{PHY}$ & effect & & 0.237 & 0.104 & 0.439 & 0.763 & 0.339 & 0.974 & 0.663 & 0.969 & $0.064^{\top}$ & 0.536 & 0.249 & 0.565 & 0.735 & 0.819 & 0.437 \\
\hline
\end{tabular}

${ }^{a, b, c}$ Columns means with different superscripts differ significantly at $P<0.05$

${ }^{1}$ Data are means of 10 broilers for each treatment; ${ }^{2} \mathrm{Axtra} \otimes \mathrm{PHY} 5000 \mathrm{~L}(1000 \mathrm{FTU} / \mathrm{kg}$ feed $) ;{ }^{3}$ Control group; ${ }^{4}$ Data were analysed as $4 \times 2$ factorial arrangement

T-Cho: total cholesterol; HDL-C: high-density lipoproteins cholesterol; TG: triglycerides; T-Pro: total protein; Alb: albumin; T-Bil: total bilirubin; Cre: creatinine; UA: uric acid; BUN: urea; Ca: calcium; IP: inorganic phosphorus; Mg: magnesium; ALT/GPT: alanine aminotransferase; AST/GOT: aspartate aminotransferase; GGT: gamma-glutamyltransferase 
On the other hand, Leske \& Coon (1999) reported that phytates from different ingredients are not similarly susceptible to dephosphorylation and that the reactive phytate content, and not total, is critical in determining the responses to supplemental phytase. They also found for example that canola meal contained a relatively high level of total phytate, but less reactive phytate, and did not respond well to added phytase. On the contrary, lyayi et al. (2013) showed that microbial phytase (Aspergillus oryzae; $1000 \mathrm{FTU} / \mathrm{kg}$ ) could have beneficial effects on black-eyed pea and peanut flour diets in broiler chickens. Furthermore, Cowieson \& Adeola (2005) and Juanpere et al. (2005) found that phytase in combination with carbohydrase and protease had additive effects in nutritionally marginal broiler diets.

The effects of dietary LF-SFM and microbial phytase inclusion or interaction between level and enzyme on carcass characteristics, internal organ weight and $\mathrm{pH}$ of the cecal digesta of broiler chickens (at day 42) are summarized in Table 5 . The interaction between the main factors (LF-SFM $\times$ phytase) had no significant effects $(P>0.05)$ on carcass yield, breast yield, abdominal fat, and digestive organ weight or cecal $\mathrm{pH}$ of broilers. However, increasing the level of LF-SFM (50\% and $75 \%)$ in diets reduced abdominal fat $(P$ $<0.001)$, whereas, the weight of small intestine was increased $(P<0.001)$ and tended $(P=0.096)$ to increase gizzard weight. Broilers fed diets that contained phytase or did not had no effect on carcass yield, breast yield, abdominal fat and digestive organ weight (i.e. gizzard, liver, pancreas, and spleen) and cecal pH $(P$ $>0.05$ ). Laudadio et al. (2014b) found that the substitution of SBM with micronized air-classified SFM (172 $\mathrm{g} / \mathrm{kg}$ ) as the main protein source had no adverse effect on growth performance and dressing percentage, and improved the breast and thigh muscle relative weights of the turkeys. Alagawany et al. (2017) observed that increasing dietary inclusion of sunflower meal $(0 \%, 25 \%, 50 \%$, and $75 \%$ replacing SBM) in broiler diets negatively influenced abdominal fat percentage. Araújo et al. (2011) reported that use of sunflower meal up to $15 \%$ in the broiler diets did not influence growth performance and carcass and yield from 22 to 42 days old. On the contrary, the inclusion of sunflower meal $(0 \%, 8 \%, 16 \%$, and $24 \%)$ in chick diets negatively influenced performance and carcass parameters (Araújo et al., 2014). Brenes et al. (2008) found that including $250 \mathrm{~g} / \mathrm{kg}$ of sunflower seeds in broiler diets caused a negative effect on relative liver weight and relative duodenum, jejunum, ileum and ceca lengths. In the current study, the increased weights of the small intestine when feeding diets with SFM (50\% and $75 \%)$ to replace SBM for the entire rearing period could be the result of dietary fibre (DF). In general, DF ingestion leads to increased size and length of the digestive organs, including the small intestine, colon, and caecum of broilers (lji et al., 2001). These effects are often associated with modification of the gut epithelium morphology, and consequently with the hydrolytic and absorptive functions of the epithelium. Ciurescu et al. (2017) also observed an increase in the relative weight of the small intestine in chickens fed with legumes beans, such as lentils (Lens culinaris; cv. Eston, green seeded and cv. Anicia, green marbled seeded).

The plasma metabolic profile of broilers is listed in Table 6. There was no interaction effect between the main factors (LF-SFM $\times$ phytase) on plasma protein, energy, mineral and enzymatic profiles, but data showed that the level of LF-SFM tended to decrease plasma BUN $(P=0.064)$. Increasing LF-SFM up to $75 \%$ to replace SBM increased plasma T-Cho $(P=0.004)$ and HDL-C $(P=0.003)$ significantly, and tended to increase TG $(P=0.080)$, Alb $(P=0.096)$, BUN $(P=0.064)$ and plasma IP concentration $(P=0.057)$, compared with control (broilers fed SBM). The inclusion of microbial phytase in the LF-SFM diets increased plasma HDL-C $(P=0.013)$ and tended to increase Mg $(P=0.088)$ concentration. Blood biochemical data are commonly used as a diagnostic tool in poultry veterinary medicine, because they can reflect the condition of the organism and the changes happening to it under the influence of nutritional and environmental factors. Thus, clinical biochemical analysis can detect metabolic disorders and subclinical diseases that affect the production efficiency. The current results agree partially with those of Rama Rao et al. (2006), who reported that increased content of SFM ( $\geq 67 \%$ of SBM) in the broiler diets had increased the concentration of HDL-C, while the concentration of low-density lipoproteins cholesterol (LDL-C) decreased. They also noticed that the serum protein and triglycerides concentration decreased progressively with the increase in dietary SFM. It is well known that higher DF content reduces dietary fat utilization by deconjugating bile salts (Story \& Furumoto, 1990), which might have reduced fat absorption through the gut. Thus, the body fat and, in particular the fat of the liver, could be used for metabolic needs and for increasing HDL serum concentration. On the other hand, Brenes et al. (2008) reported that the inclusion of $250 \mathrm{~g} / \mathrm{kg}$ of sunflower seeds in the diets of broiler chicks had a negative impact on blood parameters. Alagawany et al. (2017) also indicated that using SFM at $0 \%, 25 \%, 50 \%$, and $75 \%$ instead of SBM increased concentrations of total protein and its fractions (albumin and globulin). In contrast, Adejumo \& Williams (2006) observed that total protein, albumin, and globulin were not affected by dietary SBM being replaced by SFM at $0 \%, 25 \%, 50 \%$, and $75 \%$, during the growing period In the present study, there were no significant differences $(P>0.05)$ in the activity of ALT/GPT, AST/GOT, and GGT between treatments, that is, enzymes that are frequently used in evaluating hepatic function. Neither LF-SFM nor phytase addition had any effect on liver health. Previously, Alagawany et al. (2017) reported that the activity of ALT was enhanced with increasing the SFM level up to $50 \%$ in 
broiler diets. To the best of the authors' knowledge, there are no published studies that test the specificity between LF-SFM and Buttiauxella-derived phytase on broiler blood constituents. Viveros et al. (2002) showed that the addition of phytase (Natuphos 500) in broiler low-P diets increased plasma $P$ level and serum AST activity, reduced plasma $\mathrm{Ca}$ and Mg contents, and reduced serum ALT, and alkaline phosphatase, and lactate dehydrogenase activities.

\section{Conclusion}

The replacement of SBM in broiler chicken diets with LF-SFM at levels lower than 25\% resulted in similar productive performance, carcass and breast yield, digestive organ size and $\mathrm{pH}$ of the cecal digesta. Higher LF-SFM levels (50\% and $75 \%$ ) had a negative effect on small intestine weight, and tended to increase gizzard weight. Phytase addition had no favourable effect on BWG, FI, and FCR. The health state of the broilers was not affected. Further research about the practical implications of microbial phytase is recommended before it is applied on a commercial scale.

\section{Acknowledgements}

This study was supported financially by the Ministry of Research and Innovation of Romania, and the UEFICDI as research funding agency (Grant No. 17 PFE/ 17.10.2018, Grant No. 2018-PCCDI-8/2 and Grant No. PN 190901 04).

\section{Authors' Contributions}

GC, AV and HG contributed to experimental design, data analysis, and interpretation. GC and DG contributed to experiment care, sample processing, and data recording. GC and AV contributed to manuscript writing and manuscript preparation.

\section{Conflict of Interest Declaration}

The authors declared no conflict of interest.

\section{References}

Abdelrahman, M. M. \& Saleh, F.H., 2007. Performance of broiler chickens fed corn-sunflower meal diets with $\beta$ glucanase enzyme. Jordan J. Agric. Sci. 3(3), 272-280.

Adejumo, D.O. \& Williams, A.O., 2006. Effects of partial replacement of soya bean meal or groundnut cake with sunflower seed meal in broiler chicken diets on performance and plasma metabolites. Global J. Pure Appl. Sci. 12(2), 159-164.

Adeola, O. \& Cowieson, A.J., 2011. Board-invited review: opportunities and challenges in using exogenous enzymes to improve non-ruminant animal production. J. Anim. Sci. 89(10), 3189-3218.

Alagawany, M., Attia, A.I., Ibrahim, Z.A. \& Mahmoud, R.A., 2017. The effectiveness of dietary sunflower meal and exogenous enzyme on growth, digestive enzyme, carcass traits, and blood chemistry of broilers. Environ. Sci. Pollut. Res. 24(13), 12319-12327.

Araújo, L.F., Araujo, C.S.S., Petroli, N.B., Laurentiz, A.C., Albuquerque, R. \& Neto, M.A.T., 2011. Sunflower meal for broilers of 22 to 42 days of age. Rev. Bras. Zoo. 40(10), 2142-2146.

Araújo, W.A.G. de, Albino, L.F.T., Rostagno, H.S., Hannas, M.I., Pessoa, G.B.S., Messias, R.K.G., Lelis, G.R. \& Ribeiro, Jr.V., 2014. Sunflower meal and enzyme supplementation of the diet of 21- to 42-day-old broilers. Braz. J. Poult. Sci. 16(2), 17-24

Biehl, R. R., Baker, D. H., de Luca, H. F., 1998. Activity of various vitamin D3 analogs for improving phosphorus utilization in chicks receiving diets adequate in vitamin D3. Br. Poult. Sci. 39(3), 408-412.

Bozzo, G., Ceci, E., Bonerba, E., Desantis, S. \& Tantillo, G., 2008. Ochratoxin A in laying hens. High-performance liquid chromatography detection and cytological and histological analysis of target tissues. J. Appl. Poult. Res. 17(1), 151-156.

Brenes, A., Centeno, C., Viveros, A. \& Arija, I., 2008. Effect of enzyme addition on the nutritive value of high oleic acid sunflower seeds in chicken diets. Poult. Sci. 87(11), 2300-2310.

Canibe, N., Martin-Pedrosa, M., Robredo, L.M. \& Bach-Knudsen, K.E., 1999. Chemical composition, digestibility and protein quality of 12 sunflower (Helianthus annuus L.) cultivars. J. Sci. Food Agric. 79(13), 1775-1782.

Ciurescu, G. \& Pană, O., 2017. Effect of dietary untreated field pea (Pisum sativum L.) as substitute for soybean meal and enzymes supplementation on egg production and quality of laying hens. Rom. Biotech Lett. 22(1), 1220412213.

Ciurescu, G., Vasilachi, A., Hăbeanu, M. \& Dragomir, C., 2017. Effects of dietary lentil seeds inclusion on performance, carcass characteristics and cecal pH of broiler chickens. Indian J. Anim. Sci. 87(9), 1130-1134.

Cowieson, A.J. \& Adeola, O., 2005. Carbohydrase, protease and phytase have an additive beneficial effect in nutritionally marginal diets for broiler chicks. Poult. Sci. 84(12), 1860-1867.

Cowieson, A.J., Wilcock, P. \& Bedford, M.R., 2011. Super-dosing effects of phytase in poultry and other monogastrics. World's Poult. Sci. J. 67(2), 225-236.

Dersjant-Li, Y., Awati, A., Schulze, H. \& Partridge, G., 2015. Phytase in non-ruminant animal nutrition: A critical review on phytase activities in the gastrointestinal tract and influencing factors. J. Sci. Food Agric. 95(5), 878-896.

Iji, P.A., Saki, A. \& Tivey, D.R., 2001. Intestinal development and body growth of broiler chicks on diets supplemented with non-starch polysaccharides. Anim. Feed Sci. Technol. 89(3-4), 175-188. 
International Union of Biochemistry and Molecular Biology, 1992. Enzyme nomenclature: Recommendations of the nomenclature committee of the International Union. San Diego, CA: Academic Press.

lyayi, E. A., Fru-Nji, F. \& Adeola, O., 2013. True phosphorus digestibility of black-eyed pea and peanut flour without or with phytase supplementation in broiler chickens. Poult. Sci. 92(6), 1595-1603.

Juanpere, J., Perez-Vendrell, A.M., Angula, E., Brufau, J., 2005. Assessment of potential interaction between phytase and glycosidase enzyme supplementation on nutrient digestibility in broilers. Poult. Sci. 84(4), 571-580.

Kalmendal, R., Elwinger, K., Holm, L., Tauson, R., 2011. High-fibre sunflower cake affects small intestinal digestion and health in broiler chickens. Br. Poult. Sci. 52(1), 86-96.

Laudadio, V., Bastoni, E., Introna, M. \& Tufarelli, V., 2013. Production of low-fibre sunflower (Helianthus annuus L.) meal by micronization and air classification processes. CyTA-J. Food. 11(4), 398-403.

Laudadio, V., Ceci, E., Nahashon, S.N., Introna, M., Lastella, N.M.B. \& Tufarelli, V., 2014a. Influence of substituting dietary soybean for air-classified sunflower (Helianthus annuus L.) meal on egg production and steroid hormones in early-phase laying hens. Reprod. Dom. Anim. 49(1), 158-163.

Laudadio, V., Introna, M., Lastella, N.M.B. \& Tufarelli, V., 2014b. Feeding of low-fibre sunflower (Helianthus annus L.) meal as substitute of soybean meal in turkey rations: Effects on growth performance and meat quality. J. Poult. Sci. 51, 185-190.

Leske, K. L. \& Coon, C.N., 1999. A bioassay to determine the effect of phytase on phytate phosphorus hydrolysis and total phosphorus retention of feed ingredients as determined with broilers and laying hens. Poult. Sci., 78(8), 1151-1157.

Liu, B., Rafiq, A., Tzeng, Y. \& Rob, A., 1998. The induction and characterization of phytase and beyond. Enzyme Microb. Technol. 22(5), 415-424.

Mandal, A. B., Elangovan, A.V., Tyagi, P.K., Tyagi, P.K., Kaur, S. \& Johri, A.K., 2006. Compatibility of using rapeseed and sunflower seed meal in maize-sorghum-soy based diets for broiler chickens. Indian J. Anim. Sci. 46(9), 7579.

Mandal, A. B., Elangovan, A.V., Tyagi, Pamod K., Tyagi, Praveen K., Johri, A.K. \& Kaur, S., 2005. Effect of enzyme supplementation on the metabolisable energy content of solvent-extracted rapeseed and sunflower seed meals for chicken, guinea fowl and quail. Br. Poult. Sci. 46(1), 75-79.

de Morais Oliveira, V.R., de Arruda, A.M.V., Silva, L.N.S., de Souza, J.B.F., de Queiroz, J.P.A.F., da Silva Melo, A. \& Holanda, J.S., 2016. Sunflower meal as a nutritional and economically viable substitute for soybean meal in diets for free-range laying hens. Anim. Feed Sci. Technol. 220, 103-108.

Mushtaq, T., Sarwar, M., Ahmad, G., Mirza, M.A., Ahmad, T., Noreen, U., Mushtaq, M.M.H. \& Kamran, Z., 2009. Influence of sunflower meal based diets supplemented with exogenous enzyme and digestible lysine on performance, digestibility and carcass response of broiler chickens. Anim. Feed Sci. Technol. 149(3-4), 575-286.

NRC, 1994. Nutrient Requirements of Poultry (9th ed.). National Academy Press, Washington D.C., USA.

OJEU, 2009. Official Journal of the European Union L 54. Commission Regulation (EC) No. 152/2009 Laying Down the Methods of Sampling and Analysis for the Official Control of Feed.

Peric, L., Milic, D. \& Bjedov, S., 2010. The effect of sunflower meal on growth performance of broiler chicks. Proceedings of the 13th European Poultry Conference, 23-27 August Tours, France.

Rama Rao, S. V., Raju, M.V.L.N., Panda, A.K. \& Reddy, M.R., 2006. Sunflower seed meal as a substitute for soybean meal in commercial broiler chicken diets. Br. Poult. Sci. 47(5), 592-598.

Ravindran, V., 2013. Feed enzymes: The science, practice, and metabolic realities. J. Appl. Poult. Res. 22(3), 628-636.

Rezaei, M. \& Hafezian, H., 2007. Use of different levels of high fibre sunflower meal in commercial Leghorn type layer diets. Int. J. Poult. Sci. 6, 431-433.

Rizzello, C.G., Coda, R., Mazzacane, F., Minervini, D. \& Gobbetti, M., 2012. Micronized by-products from debranned durum wheat and sourdough fermentation enhanced the nutritional, textural and sensory features of bread. Food Res. Int. 46, 304-313.

Selle, P. H., Ravindran, V., Bryden, W.L. \& Scott, T., 2006. Influence of dietary phytate and exogenous phytase on amino acid digestibility in poultry: a review. J. Poult. Sci. 43, 89-103.

Selle, P.H., Ravindran, V., Ravindran, C. \& Bryden, W.L., 2007. Effects of dietary lysine and microbial phytase on growth performance and nutrient utilisation of broiler chickens. Asian Austral. J. Anim. 20(7), 1100-1107.

Senkoylu, N. \& Dale, N., 2006. Nutritional evaluation of a high-oil sunflower meal in broiler starter diets. J. Appl. Poult. Res. 15(1), 40-47.

Simons, P. C., Versteegh, H.A., Jongbloed, A.W., Kemme, P.A., Slump, P., Bos, K.D., Wolters, M.G., Beudeker, R.F. \& Verschoor, G.J., 1990. Improvement of phosphorus availability by microbial phytase in broilers and pigs. Br. J. Nutr. 64(2), 525-540.

SPSS. 2011. Statistics for Windows, Version 20.0. IBM Inc., Chicago, IL, USA.

Story, J.A. \& Furumoto, E.J., 1990. Dietary fibre and bile acid metabolism. In: Knitchevsky D, Bonfield C., Anderson JW, eds. Dietary fibre: Chemistry, physiology, and health effects. Plenum, New York, 365-74.

Tavernari, F.C., Albino, L.F.T., Morata, R.L., Durata, W.M.J., Rostagno, H.S. \& Viana, M.T.S., 2008. Inclusion of sunflower meal, with or without enzyme supplementation, in broiler diets. Rev. Bras. Cienc. Avíc. 10(4), $233-238$.

Viveros, A., Brenes, A., Arija, I. \& Centeno, C., 2002. Effects of microbial phytase supplementation on mineral utilization and serum enzyme activities in broiler chicks fed different levels of phosphorus. Poult. Sci. 81(8), 1172-1183. 